JURNAL KEBIDANAN

Vol 6, No 4, Oktober 2020 : 531-536

\title{
TEH HIJAU MENURUNKAN KADAR KOLETEROL TOTAL PADA IBU AKSEPTOR KB DEPOMEDROXYPROGESTERONE ACETATE (DMPA)
}

\author{
Fazdria* $^{*}$ \\ *Program Studi D-III Kebidanan Langsa Politeknik Kesehatan Kementerian Kesehatan Aceh \\ email : fadzria@poltekkesaceh.ac.id
}

\begin{abstract}
ABTRACT
Background: The type of injectable contraception currently widely used is Depo Medroxyprogesterone Acetate (DMPA) which contains the progestin hormone, a synthetic ingredient of progesterone. The mechanism of action of DMPA as contraception is to prevent ovulation. DMPA will inhibit the secretion of GnRH and Luteinizing hormone $(\mathrm{LH})$ in the preovulatory period, that ovulation will be suppressed at least in the first three months after used. That will be a hypoestrogen condition due to the use of DMPA. Estrogen is a female hormone that has many functions, one of which is as an antioxidant which helps control cholesterol levels. The role of estrogen as an antioxidant is to prevent the oxidation of $L D L$ so that the ability of $L D L$ to penetrate plaque is reduced. Endogenous and exogenous antioxidants are used to reduced free radicals in the body. Either the substances contained in plants and functions as an antioxidant to prevent oxidative stress is polyphenols. Among all types of tea and other plants containing polyphenols, polyphenols from green tea have high bioavailability. Dried green tea leaves contain $36 \%$ polyphenols and unfermented green tea contains $80 \%$ flavonoids.

Purpose: To prove the effect of brewed of green tea on total cholesterol levels in DMPA users in Working Area of Puskesmas Langsa Barat.

Methods: The study design was a quasi experimental design with a pretest posttest control group approach. Total cholesterol measurements were done before and after the treatment of green tea for 30 days. The sample consisted of 34 people and divided into two groups, the control group and the green tea brewed group, given orally 3 times a day at a rate of 1 teaspoon ( \pm 2 grams) for one time consumption.

Results: There was a difference in the average cholesterol level between the pretest and posttest in the group given green tea with a $p$-value of 0.015 ( $p$-value $<0.05$ ), which means that green tea was able to significantly reduced cholesterol levels in DMPA users.

Conclusion: There is a difference in the average cholesterol levels in the control and treatment groups. Consumption of green tea was able to significantly reduced cholesterol levels in the experimental group. Suggested: The results of this study can be used as a reference as an alternative treatment of hypercholeterolmia caused by used of DMPA.

Suggestion This research needs to be refined to improve the accuracy of the cholesterol examination results using the POCT (Point of Care Testing) method or the spectrophotometer method considering that the cholesterol examination method used in this study is the strip-test method. Furthermore, it is necessary to control confounding factors such as body weight, diet and physical activity of the respondents
\end{abstract}

Keywords: Green tea, Cholesterol, DMPA, Contraception.

\begin{abstract}
ABSTRAK
Latar Belakang : Jenis kontrasepsi suntik yang saat ini banyak digunakan adalah Depo Medroxyprogesterone Acetate (DMPA) yang mengandung hormon progestin yaitu bahan sintestis dari progesteron. Mekanisme kerja DMPA sebagai kontrasepsi adalah dengan mencegah ovulasi. DMPA akan menghambat sekresi $\mathrm{GnRH}$ dan Luteinizing hormone (LH) pada masa preovulatorik sehingga ovulasi akan tertekan minimal pada tiga bulan pertama penggunaan. Sehingga akan terjadi kondisi hipoestrogen akibat pengunaan DMPA. Estrogen merupakan hormon wanita yang memiliki banyak fungsi, salah satunya adalah sebagai antioksidan yang membantu mengendalikan kadar kolestrol. Peranan estrogen sebagai antioksidan adalah mencegah proses oksidasi LDL sehingga kemampuan LDL untuk menembus plak akan berkurang. Antioksidan endogen dan eksogen digunalan untuk menurunkan radika bebas dalam tubuh. Salah satu zat yang terdapat dalam tanaman dan berfungsi sebagai antioksidan untuk mencegah stress oksidatif adalah polifenol. Diantara semua jenis teh dan tanaman lain yang mengandung polifenol, polifenol dari teh hijau mempunyai kemampuan bioavaibilitas yang
\end{abstract}


tinggi. Daun teh hijau kering mengandung $36 \%$ polifenol dan teh hijau yang tidak mengalami fermentasi mengandung $80 \%$ flavonoid.

Tujuan Penelitian : Membuktikan pengaruh seduhan teh hijau terhadap kadar kolesterol total pada ibu akseptor KB DMPA di Wilayah kerja Langsa Barat

Metode Penelitian : Rancangan penelitian ini adalah quasi experimental design dengan pendekatan pretest posttest control group. Pengukuran total kolesterol dilakukan sebelum dan setelah perlakuan pemberian seduhan teh hijau selama 30 hari. Sampel berjumlah 34 orang dan dibagi kedalam dua kelompok yaitu kelompok control dan kelompok seduhan teh hijau diberikan secara oral 3 kali sehari dengan takaran 1 sendok teh ( $\pm 2 \mathrm{gr}$ ) untuk sekali konsumsi.

Hasil Penelitian : Terbapat perbedaan rata-rata kadar kolesterol antara pretest dan posttest pada kelompok yang diberi teh hijau dengan $p$-value $0,015(p$-value $<0,05)$ yang berarti teh hijau mampu menurunkan kadar kolesterol secara signifikan pada akseptor KB DMPA.

Kesimpulan : Ada perbedaan rata-rata kadar kolesterol pada kelompok kontrol dan perlakuan. Konsumsi teh hijau mampu menurunkan kadar kolesterol pada kelompok eksperimen secara signifikan. Disarankan : Hasil penelitian ini dapat dijadikan referensi sebagai pengobatan alternatif hiperkoleterolmia akibat pengguna DMPA.

Saran : Penelitian ini perlu disempurnakan untuk meningkatkan keakuratan hasil pemeriksaan kolesterol dengan metode POCT (Point of Care Testing) atau metode spektrofotometer mengingat metode pemeriksaan kolesterol yang digunakan dalam penelitian ini adalah dengan metode strip-test. Selanjutnya diperlukan untuk mengontrol fakkor perancu seperti berat badan, pola makan dan aktifitas fisik responden

Kata Kunci : Teh hijau, Kolesterol, DMPA, Kontrasepsi.

\section{PENDAHULUAN}

Keluarga berencana telah menjadi salah satu sejarah keberhasilan pada abad ke-20. Pada tahun 2019, ada 922 juta wanita usia subur diseluruh dunia menggunakan kontrasepsi. Keluarga berencana merupakan upaya pelayanan kesehatan preventif yang paling dasar dan utama serta pencegahan kematian (United Nations, 2019). Dewasa ini peran Keluarga Berencana, tidak hanya dimaknai sebagai upaya pengendalian kelahiran semata, akan tetapi juga sebagai upaya mewujudkan keluarga sejahtera dengan membangun kesadaran setiap keluarga agar memiliki dukungan sosial budaya, ekonomi, pendidikan, dan kesehatan (BKKBN, 2018). Kontrasepsi juga memberikan manfaat dalam melindungi kesehatan reproduksi yang komprehensif. Presentase pemakaian alat kontrasepsi menunjukkan peningkatan dari 62 persen pada SDKI 2012 menjadi 64 persen pada SDKI 2017. Namun, Persentase putus pakai (Drop Out) kesertaan ber KB masih tinggi yaitu 34 persen. Selain itu, menurut WHO 490.000 perempuan di dunia setiap tahun didiagnosa terkena kanker serviks dan 80 persen berada di negara berkembang termasuk Indonesia (BKKBN, 2019). Hasil Susenas tahun 2015 secara nasional menunjukkan capaian angka pemakaian kontrasepsi jangka panjang (MOP, MOW, IUD, dan implan) sebesar 10,2\% dengan metode kontrasepsi yaitu suntikan $(44,7 \%)$, pil (20,2\%), MOW (13,5\%), IUD (11\%), implant $(5,3 \%)$, kondom $(4,5 \%)$ dan MOP $(0,7 \%)$ (Ekoriano \& Novita, 2018).
DMPA merupakan salah satu metode kontrasepsi yang paling efektif yang saat ini banyak digunakan (Abasiattai, Udoma, \& Ukeme, 2010). DMPA mengandung hormon progestogen sintetik (progestin) yang mempunyai struktur kimia seperti progesterone (Bronshtein, Krol, Schlesinger, \& Altstein, 2012). Mekanisme kerja DMPA sebagai kontrasepsi adalah dengan mencegah ovulasi. DMPA akan menghambat sekresi $\mathrm{GnRH}$ dan Luteinizing hormone (LH) pada masa preovulatorik sehingga ovulasi akan tertekan minimal pada tiga bulan pertama penggunaan (Nelson, 2010). Hasil penelitian menyatakan terdapat perbedaan kadar kolesterol total dan HDL antara akseptor pil kombinasi dan DMPA, namun secara statistik tidak terdapat perbedaan yang bermakna (Lestari, Rita, \& Yusrawatib, 2019). Hiperkolesterolmia akan memicu terjadinya stress oksidatif (Stapleton, Goodwill, James, Brock, \& Frisbee, 2010). Stress oksidatif akibat DMPA dipicu karena rendahnya estrogen endogen. Stress oksidatif pada pengguna DMPA diperantai oleh rendahnya kadar estrogen endogen. DMPA bekerja pada pola hipotalamus-hipofisisovarium dengan menghambat Gonadotropin Realising Hormon ( $\mathrm{GnRH}$ ) pada hipofisis sehingga tidak terjadinya ovulasi dan penurunan sirkulasi estrogen (Spevack, 2013). Hasil penelitian menyatakan stress oksidatif akibat DMPA yang ditandai dengan penurunan kadar enzim SOD ovarium tikus (Veri, Aulia, Ratnawatid, Hidayati, Noorhamdani, \& Dwijayasa, 2015). 
Antioksidan endogen dan eksogen digunakan untuk menurunkan radika bebas dalam tubuh. Antioksidan eksogen yang terdapat dalam bahan herbal atau tanaman obat adalah lebih aman dan telah banyak digunakan sejak dulu. Salah satu tanaman yang berfungsi sebagai antioksidan untuk mencegah stress oksidatif adalah teh hijau (Susil, Indriati, \& Rustianti, 2012) .

\section{METODELOGI PENELITIAN}

Rancangan penelitian ini adalah quasi experimental design dengan pendekatan pretest posttest control group (Masturoh \& Nauri, 2018). Pengukuran total kolesterol dilakukan sebelum dan setelah perlakuan pemberian seduhan teh hijau selama 30 hari (Ariani \& Sutriningsih, 2017). Penelitian dilakukan di Desa Paya Bujok Teungoh Kec. Langsa Barat Kota Langsa dari tanggal $1 \mathrm{~s} / \mathrm{d} 30$ September 2018. Populasi menggunakan kriteria inklusi yaitu usia 20-35 tahun, lama pemakaian DMPA > 1 tahun. Sampel dikelompokkan kedalam 2 kelompok yaitu kelompok perlakuan teh hijau dan kelompok kontrol. Masing-masing kelompok berjumlah 17 orang sampel.

Teh hijau yang digunakan adalah teh hijau celup komersil merk kepala djenggot dengan netto 2 gr yang diberikan secara oral 3 kali sehari dengan takaran 1 sendok teh ( \pm 2 gr) untuk sekali konsumsi dengan cara diseduh selama 15 menit dengan suhu $95^{\circ} \mathrm{C}$ (Fajar, Wrasiati, \& Suhendra, 2018). Berdasarkan hasil penelitian tidak ada perbedaan signifikan kandungan fenol dalam teh komersil (Goalpara Selected Green Tea, Sariwangi Teh Hijau Asli, Green Tea Sosro Celup, Teh Hijau Cap Kepala Jenggot dan Teh Hijau Cap Botol) (Bayani \& Mujaddid, 2015). Kolesterol total adalah pengukuran dari kolesterol LDL, kolesterol HDL dan komponen lipid lainnya dengan kadar normal kurang dari 200 $\mathrm{mg} / \mathrm{dl}$ (P2PTM Kemenkes RI, 2019) . Kadar Kolesterol total diukur dengan cara menggunakan alat easy touch dengan metode electrode-based biosensor pada satu hari sebelum perlakuan untuk pretest dan pada hari ke 31 (sehari setelah selesai perlakuan).

\section{HASIL PENELITIAN \\ Analisis Univariat}

Berdasarkan tabel diatas mayoritas responden berusia 20-35 tahun berjumlah 32 orang $(94.12 \%)$ dan mayoritas lama pemakaian DMPA adalah $1-3$ tahun $(38,24 \%)$.

Tabel 1.

Distribusi Frekuensi Umur dan Lama Pemakaian DMPA Responden

\begin{tabular}{lcc}
\hline \multicolumn{1}{r}{ Variabel } & Frekuensi & Persentase (\%) \\
\hline Usia Responden & 0 & \\
$<20$ tahun & 32 & $0 \%$ \\
20-35 tahun & 2 & $94.12 \%$ \\
$>35$ tahun & & $5.88 \%$ \\
Lama Pemakaian DMPA & 13 & \\
1-3 tahun & 11 & $38.24 \%$ \\
3-5 tahun & 10 & $32.35 \%$ \\
$>5$ tahun & 34 & $29.41 \%$ \\
Total & & 100 \\
\hline
\end{tabular}

\section{Analisis Bivariat}

Tabel 2.

Pengaruh Konsumsi Teh Hijau Terhadap Kadar Kolesterol Total

\begin{tabular}{lcccccc}
\hline \multirow{2}{*}{ Kelompok } & \multicolumn{2}{c}{$\begin{array}{c}\text { Rata-rata Kadar } \\
\text { Kolesterol Total }\end{array}$} & $\begin{array}{c}\text { Mean } \\
\text { Paired }\end{array}$ & $\begin{array}{c}\text { Std. } \\
\text { Deviation }\end{array}$ & Correlation & $\boldsymbol{P}_{\text {value }}$ \\
\cline { 2 - 3 } Kontrol & Pretest & Postest & & & \\
Teh Hijau & 207,76 & 202,94 & 6.76 & 1.832 & 5.88 & 0.371 \\
\hline
\end{tabular}

Berdasarkan uji Paired T test, tampak perbedaan rata-rata kadar kolesterol total pada kedua kolompok. Pada kelompok kontrol rata-rata kadar kolesterol pretest adalah 207,76 mg/dl dan turun pada saat posttest menjadi 202,94 mg/dl. Pada kelompok eksperimen (pemberian teh hijau) didapatkan rata-rata kadar kolesterol pretest 205,47 $\mathrm{mg} / \mathrm{dl}$ dan turun menjadi $185,59 \mathrm{mg} / \mathrm{dl}$ saat posttest. 
Pada tabel diatas juga tampak adanya korelasi rata-rata kadar kolesterol pada kelompok kontrol pada saat pretest dan posttest dengan nilai korelasi $0,934(0,000)$. Nilai sig 0,270 . Karena $p$ value $>0,05$ maka dapat disimpulan Ho diterima, artinya tidak terdapat perbedaan rata-rata kadar kolesterol pada saat pretest dan posttest kelompok kontrol pengguna DMPA. Sedangkan pada kelompok perlakuan konsumsi teh hijau didapatkan $p$-value $0,015(p$-value $<0,05)$ yang berarti terbapat perbedaan rata-rata kadar kolesterol antara pretest dan posttest pada kelompok yang diberi teh hijau. Dengan demikian dapat dinyatakan bahwa teh hijau mampu menurunkan kadar kolesterol secara signifikan pada akseptor KB DMPA.

\section{PEMBAHASAN}

Hasil penelitian ini menunjukkan konsumsi teh hijau mampu menurunkan kadar kolesterol pada pengguna DMPA. Pemakaian DMPA memicu kenaikan kolesterol pada ibu (Wulandari \& Suriati, 2019). Hasil penelitian membuktikan ada hubungan yang signifikan antara lama pemakaian kontrasepsi suntik DMPA dengan kadar kolesterol pada akseptor KB DMPA (Prawerti, Runiari, \& Ruspawan, 2019). DMPA meningkatkan total cholesterol pada wanita usia 15-49 tahun (Farooq, Aamir, \& Baig, 2018). Menurut iqmy dan yulis tahun 2016,pemilihan kontrasepsi suntik 3 bulan responden sangat tinggi disebabkan karena beberapa factor diantaranyamudah memperolehnya dan harga terjangkau.

Penelitian ini sejalan dengan penelitian lain yang menyatakan bahwa ekstrak teh hijau menghambat peningkatan LDL yang diakibatkan oleh induksi DMPA pada tikus (Susilawati, Barlianto, \& Wiyasa, 2015). Ekstrak teh hijau menurunkan kadar kolesterol total tikus model diabetes (Sarel \& Simajuntak, 2020). Hasil penelitian lain tentang seduhan teh hijau yang direndam pada telur asin selama 3 hari mampu menurunkan kadar kolesterol pada telur asin (Hidayati \& Sulistyawati, 2016). Kenaikan kolesterol ini diduga berhubungan dengan kondisi hipoestrogen pada pengguna DMPA.

Penelitian lain menyatakan pemberian teh hijau pada mencit jantan yang diberi diit tinggi lemak dapat mencegah kenaikan kadar kolesterol total (Ekanto, Marhamah, \& Silvyana, 2015). Hasil penelitian juga menyatakan bahwa teh hijau mampu melindungi vascular di endometrium dan meningkatkan jumlah sel endotel yang sebelumnya mengalami kerapuhan akibat paparan DMPA pada mencit (Veri, AS, Mutiah, Seriana, \& Malinda, 2019). Penelitian lain juga menyatakan bahwa seduhan teh hijau dosis tinggi mampu meningkatkan jumlah arteri spiralis dan ketebalan lapisan endometrium pada uterus tikus yang disuntik DMPA (AS, Veri, \& Alchalidi, 2017).

Pemakaian DMPA akan menurunkan level estrogen dan menurunkan ekspresi estrogen receptor-a (ER-a) (Fitrianingtyas \& Anggreni, 2019). Estrogen endogen berfungsi sebagai antioksidan estrogen mampu meregulasi estrogen receptors dan ekspresi gen antioksidan pada otot skeletal tikus (Baltgalvis, Greising, Warren, \& Lowe, 2010). Kenaikan kolesterol terjadi karena adanya stress oksidatif. Ekstrak teh hijau mengandung polifenol yang merupakan antioksidan non-enzimatis atau antioksidan sekunder. Aktivitas antioksidan ekstrak hijau dipengaruhi oleh jumlah senyawa flavonoid, semakin banyak senyawa flavonoid maka aktivitas antioksidan akan semakin meningkat (Rohman, Riyanto, \& Hidayati, 2007). Teh hijau mengandung katekin yang berfungsi sebagai kelator alami (Hernayanti, Moeljopawiro, Sadewa, Sasongko, \& Hidayah, 2019). Katekin dan EGCG dalam teh hijau mampu melawan obesitas, hypercholesterolemia dan hyperglycemia (Ahmad, et al., 2015).

\section{SIMPULAN}

Dari hasil penelitian ini dapat disimpulkan bahwa ada perbedaan kadar kolesterol total pada ibu pengguna DMPA antara sebelum dan sesudah konsumsi teh hijau. Seduhan teh hijau mampu menurunkan kadar kolesterol pada pengguna KB DMPA.

\section{SARAN}

Penelitian ini perlu disempurnakan untuk meningkatkan keakuratan hasil pemeriksaan kolesterol dengan metode POCT (Point of Care Testing) atau metode spektrofotometer mengingat metode pemeriksaan kolesterol yang digunakan dalam penelitian ini adalah dengan metode strip-test. Selanjutnya diperlukan untuk mengontrol fakkor perancu seperti berat badan, pola makan dan aktifitas fisik responden.

\section{DAFTAR PUSTAKA}

Abasiattai, A. M., Udoma, E. J., \& Ukeme, E. (2010). Depot Medroxyprogesterone Injectable Contraception At The University Of Uyo Teaching Hospital, Uyo. Annals of African Medicine, 9 (2), 81-85.

Ahmad, R. S., Butt, M. S., Sultan, M. T., Mushtaq, Z., Ahmad, S., Dewanjee, S., et al. (2015). Preventive Role Of Green Tea Catechins Fromobesity And Related Disorders Especiallyhypercholesterolemia And 
Hyperglycemia. Journal of Translational Medicine, 13 (79), 1-9.

Ariani, N. L., \& Sutriningsih, A. (2017). Peran Konsumsi Teh Hijau ( Camelia Sinensis ) Terhadap Penurunan Indeks Massa Tubuh (IMT) Mahasiswa Keperawatan Universitas Tribhuwana Tunggadewi. Jurnal Care, 5 (2), 194-204.

AS, E., Veri, N., \& Alchalidi, A. (2017). High Dose Of Green Tea Infusion Normalized Spiral Artery Density In Rats Treated With The DepotMedroxyprogesterone Acetate. Journal of Intercultural Ethnopharmacol, 6 (1), 65-67.

Baltgalvis, K. A., Greising, S. M., Warren, G. L., \& Lowe, D. A. (2010). Estrogen Regulates Estrogen Receptors and Antioxidant Gene Expression in Mouse Skeletal Muscle. Plos One, 1-11.

Bayani, F., \& Mujaddid, J. (2015). Analisis Fenol Total Teh Hijau Komersial (Camellia sinensisL). Jurnal IImiah Pendidikan Kimia", Hydrogen", 3 (2), 318-323.

BKKBN. (2018). KB Membangun Kesadaran Terciptanya Keluarga Sejahtera. https://www.bkkbn.go.id/detailpost/kbmembangun-kesadaran-terciptanya-keluarga sejahtera

BKKBN. (2019). BKKBN Tingkatkan Jumlah Kesertaan KB dan Kesadaran Masyarakat Akan Kesehatan Reproduksi Melalui Bakti Sosial Dalam Rangka Peringatan Harganas XXVI Tahun 2019. https://www.bkkbn.go.id/detailpost/bkkbntingkatkan-jumlah-kesertaan-kb-dankesadaran-masyarakat-akan-kesehatanreproduksi-melalui-bakti-sosial-dalamrangka-peringatan-harganas-xxvi-tahun2019

Bronshtein, A., Krol, A., Schlesinger, H., \& Altstein, M. (2012). Development of Immunochemical Methods for Purification and Detection of the Steroid Drug Medroxyprogesterone Acetate . Journal of Environmental Protection, 2012 (3), 624-639.

Ekanto, B., Marhamah, E., \& Silvyana, Y. (2015). Pemberian Teh Hijau Terhadap Kadar Kolesterol Total Mencit Jantan yang Diberi Diit Tinggi Lemak. Jurnal keperawatan Karya Bhakti, 18-25.

Ekoriano, M., \& Novita, F. (2018). Dinamika Pemakaian Kontrasepsi Modern Di Indonesia (Analisis Data Susenas 2015). Jurnal Kependudukan Indonesia, 27-38.

Fajar, R. I., Wrasiati, L. P., \& Suhendra, L. (2018). Kandungan Senyawa Flavonoid Dan Aktivitas
Antioksidan Ekstrak Teh Hijau Pada Perlakuan Suhu Awal dan Lama Penyeduhan. Jurnal Rekayasa dan Manajemen Agroindustri, 6 (3), 196-202.

Farooq, Aamir, \& Baig. (2018). Association Of Hba1C And Total Cholesterol Levels In Child Bearing Age Using Injectable Contraceptives. Journal of Muhammad Medical College, 8 (2), 45-48.

Fitrianingtyas, R., \& Anggreni, E. (2019). Pengaruh Depo Medroksi Progesteron Asetat (DMPA) Terhadap Ekspresi Estrogen Receptor-a (ERa) Pada Endometrium Tikus (Rattus Norvegicus) Yang Dipapar. Jurnal Ilmiah Kebidanan, 5 (1), 38-43.

Hernayanti, Moeljopawiro, S., Sadewa, A. H., Sasongko, N. D., \& Hidayah, H. A. (2019). Katekin dalam Teh Hijau sebagai Kelator Alami pada Individu Terpapar Plumbum Pembawa Polimorfisme Gena Nitrit Oksida Sintase 3. Majalah IImiah Biologi Biosfera : A Scientific Journal, 36 (2), 90-98.

Hidayati, N., \& Sulistyawati, D. (2016). Pengaruh Perendaman dalam Seduhan Teh Hijau Selama Tiga Hari Pasca Pengasinan terhadap KadarKolesterol Kuning Telur. Biomedika, 54-59.

Iqmi, L. O., Evayanti, Y., \& Hidayati, N. (2016). Hubungan antara penggunaan KB 3 Bulan dengan siklus menstruasi di Puskesmas Simpur Rawat Inap Tanjung Karang Pusat Tahun 2015. Jurnal Kebidanan Malahayati, 2(1).

Lestari, H., Rita, R. S., \& Yusrawatib. (2019). Perbandingan Kadar Kolesterol Total Dan HDL Antara Akseptor KB Pil Kombinasi Dengan Dmpa. Indonesia Jurnal Kebidanan, $3(1), 1-10$.

Masturoh, I., \& Nauri, A. (2018). Metodologi Penelitian Kesehatan. Jakarta: Pusat Pendidikan SDM Kesehatan BPSDMK.

Nelson, A. L. (2010). DMPA: battered and bruised but still needed and used in the USA. Journal Expert Review of Obstetrics \& Gynecology, 5 (6), 673-686.

P2PTM Kemenkes RI. (2019). Berapa Nilai Normal Kolesterol Total? http://p2ptm.kemkes.go.id/infographicp2ptm/hipertensi-penyakit-jantung-danpembuluh-darah/berapa-nilai-normalkolesterol-total

Prawerti, N. M., Runiari, N., \& Ruspawan, I. D. (2019). Lama Pemakaian Kontrasepsi Suntik Depo Medroksiprogesteron Asetat Dengan 
Kadar Kolesterol Pada Akseptor KB . Jurnal Gema Keperawatan, 12 (1), 69-77.

Rohman, A., Riyanto, S., \& Hidayati, N. K. (2007). Aktivitas Antioksidan, Kandungan Fenolik Total Dan Flavonoid Total Daun Mengkudu (Morinda Citrifolia L.). Agritech, 27 (4), 147151.

Sarel, Z., \& Simajuntak, K. (2020). Pengaruh Pemberian Ekstrak Teh Hijau (Camellia sinensis L.) Terhadap Penurunan Kadar Kolesterol Total Tikus Wistar (Rattus Norvegicus) Diabetes Induksi Aloksan. Jurnal Sehat mandiri, 15 (1), 98-111.

Spevack, E. (2013). The Long-term Health Implications of Depo-Provera. Integrative Medicine, 12 (1), 27-43.

Stapleton, P. A., Goodwill, A. G., James, M. E., Brock, R. W., \& Frisbee, J. C. (2010). Hypercholesterolemia and microvasculardysfunction: interventional strategies. Journal of Inflammation, 54 (7), 110.

Susil, H., Indriati, D., \& Rustianti, A. (2012). Pengaruh Penambahan Ekstrak Daun Teh Hijau (Camelia Sinensis (L). Kuntze Var.
Assamica) Sebagai Antioksidan Pada Sediaan Gel. Fitofarmaka, 2 (2), 126-136.

Susilawati, E., Barlianto, W., \& Wiyasa, W. A. (2015). Cholesterol/Hdl-C Ratio Lowering Effect Of Green Tea In Rats Exposed To Depot Medroxiprogesterone Acetate. Journal of Experimental and Integrative Medicine, 5 (3), 165-167.

United Nations. (2019). Contraceptive Use by Method 2019. New York: United Nations.

Veri, N., AS, E., Mutiah, C., Seriana, I., \& Malinda, R. (2019). Protective Effect Of Green Tea On Tunica Adventitia And Endothelial Changes Resulting From Depot Medroxy Progesterone Acetate. Journal of Taibah University Medical Sciences, 14 (1), 8-13.

Veri, N., Aulia, F., Ratnawati, R., Hidayati, D. Y., Noorhamdani, N., \& Dwijayasa, P. M. (2015). Protective Effect Of Green Tea Againstovarian And Endometrial Apoptoses In Ratstreated With Depot Medroxyprogesteroneacetate. Biomarkers and Genomic Medicine, 7 (2015), 105-109.

Wulandari, P. C., \& Suriati. (2019). Gambaran Kadar Kolesterol pada Akseptor Suntik. Jaringan Laborotorium Medis, 1 (2), 59-65. 